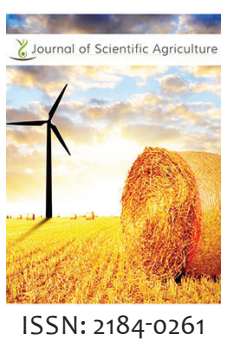

Received: January 20,2020 Accepted: March 22,2020 Published: April 07, 2020

*Corresponding Author: Edgar Muhumuza

edgarmuhumuza.em@gmail.com Keywords: Processing attributes, GCA, SCA, Potato, Uganda

\title{
Combining ability analysis of dry matter content, reducing sugars and yield of potato (Solanum tuberosum L.) genotypes in Uganda
}

\author{
Edgar Muhumuza',", Richard Edema', Prossy Namugga², Alex Barekye ${ }^{2}$ \\ ${ }^{1}$ College of Agricultural and Environmental Sciences, Makerere University, PO Box 7062, Kampala, Uganda \\ ${ }^{2}$ Kachwekano Zonal Agricultural Research and Development Institute, National Agricultural Research Organization, \\ P.O Box 421, Kabale, Uganda
}

\begin{abstract}
Potato (Solanum tuberosum L.) in Uganda is a major food and cash crop mainly grown in the highland regions by small-scale farmers. The increasing importance of potato as a processed product requires new varieties possessing quality processing attributes with acceptable yield. The objectives of this study were to estimate the combining ability effects for dry matter content, reducing sugars, and yield related traits in potato. Nineteen Fl families generated from eight parents using a half diallel mating design were evaluated for dry matter content, reducing sugars, average weight per tuber and total tuber yield at Kachwekano research station. Additive genetic effects were predominant for dry matter content while non-additive effects for the other traits. The GCA/SCA ratios were $0.58,0.28,0.17$ and 0.44 for dry matter content, reducing sugars, average weight per tuber and total tuber yield respectively. Broad sense heritability estimates were $50.6 \%$ for dry matter content, $77.8 \%$ for reducing sugars, $90.3 \%$ for average weight per tuber and 29.5\% for total tuber yield. Parents NAROPOT 3 and 395096.2 had desirable GCA effects for both dry matter content and reducing sugars. Families of nkrk19.17 x Rutuku had desirable SCA effects for dry matter content while Rutuku x 393077.54 and nkrk19.17 x 392657.8 had desirable SCA effects for reducing sugars. Additive genetic effects for dry matter content imply that, genetic gains can be achieved through different selection methods and trait transferred to the respective progenies. The selected parents and families will be subjected to further clonal

evaluation and selection.
\end{abstract}

\section{INTRODUCTION}

Globally potato (Solanum tuberosum L.) is the fourth most important staple crop after maize, rice and wheat [1]. Potato is a major food and cash crop in the highland regions of many African countries, and is mainly grown by small-scale farmers [2]. Potato is among the 15 major food crops in Uganda and is classified among the roots and tubers. During the year of 2017, Uganda had an annual potato production of 173,244 tons harvested from an area of 39,374 ha [3]. The potato crop in Uganda, especially in the districts of Kabale and Kisoro is a major source of food and cash income [4]. Majority of the potato produced is increasingly being processed into chips and crisps through retail outlets and home consumption [5]. Despite the growing importance of processing in the Ugandan potato industry, there is limited availability of potato varieties within the Ugandan market with specific infusion of particular tuber processing attributes to fit into the processing and marketing chain. These processing attributes of dry matter content and reducing sugars have not received sufficient research attention in Uganda as there seems to be limited information regarding their inheritance, and this together with the few available varieties possessing quality processing attributes has resulted into a demand deficit which is bound to affect the income security of the resource poor farmers in the highland areas as they sell $60-70 \%$ of their crop production $[4,5,6,7]$. Processing attributes of dry matter content and reducing sugars are quantitative traits that are affected by genetic factors of the plant besides environmental conditions [8]. Dry matter content is the main determinant for processing quality with values of $\geq 20 \%$ producing fried products of high yield $[9,10,11,12,13]$. Low reducing sugar content of tubers is a target for potato chips and crisp production $[14,15,16]$. In particular, the reducing sugar concentration is of importance in fried products as

Copyright: (-) The authors. This article is open access and licensed under the terms of the Creative Commons Attribution License (http://creativecommons.org/licenses/by/4.0/) which permits unrestricted, use, distribution and reproduction in any medium, or format for any purpose, even commercially provided the work is properly cited. Attribution - You must give appropriate credit, provide a link to the license, and indicate if changes were made. 
fructose and glucose participate in a Maillard reaction with amino acids to promote colour changes during frying $[12,17]$. Potatoes with reducing sugar contents less than $2 \%$ or less than 2.5-3 milligrams per gram of potato $(\mathrm{mg} / \mathrm{g})$ are considered ideal for fry processing $[12,14,16]$. But an upper limit of $5 \mathrm{mg} / \mathrm{g}$ is acceptable for chips production [12].

Even though some findings in Uganda suggest additive genetic effects predominant for dry matter content in potato [18]. Detailed information regarding inheritance of dry matter content, reducing sugars levels and combining abilities of parents has received limited attention. The knowledge of the combining ability and the mode of gene actions of dry matter content and reducing sugars will be of importance as it will facilitate the development of appropriate breeding strategies for screening and selection of good tuber processing attributes for locally developed progenies and avail new varieties with processing potential $[19,20]$. This is accompanied by the growing need for potato varieties that posses quality processing attributes coupled with high yields. This study was therefore undertaken to determine the combining ability effects for processing attributes of dry matter content, reducing sugars and yield related traits in potato. This will facilitate the development of potato clones possessing quality processing attributes with acceptable yield.

\section{MATERIALS AND METHODS}

\section{Parental Material and Crosses}

Eight genetically variant genotypes were selected and used as parents. Two of the parents were released varieties and six advanced breeder clones from National Potato Program of Uganda with variable levels of dry matter content from $17 \%$ to $20 \%$ and reducing sugar levels of $1.8 \mathrm{mg} / \mathrm{g}$ to $11 \mathrm{mg} / \mathrm{g}$ (Table 1 ). These materials were selected based on their medium to high yields, reducing sugar levels and dry matter content. Crosses were made using a half diallel mating design to generate 19 progeny families (Table 1). Controlled hand pollination was performed at flowering following emasculation during morning hour. At maturity, berries of the same cross were harvested and bulked. In total, 19 families were generated.

\section{Planting Site}

The study was carried out at Kachwekano Zonal Agricultural Research and Development Institute (KAZARDI) located at $1^{0}$ 15’07.04"S 29056'25.06”, 2,204 meters above sea level (m.a.s.l). The soil's classification are generally of typic palehumult [23], with bi-modal rainfall pattern separated by a dry spell ranging from 30 to 60 days.

\section{Experimental Design and Trial Establishment}

The potato seed obtained from successful crosses was sown in plastic seed boxes filled with heat sterilized soil for germination to obtain Fl progeny seedlings for evaluation. When the seedlings attained 3-5 leaves stage, they were transplanted in
Table 1: Characteristics of Parental genotypes used in the study

\begin{tabular}{|c|c|c|c|c|c|c|c|c|}
\hline Genotype & TS & SC & $\mathrm{FC}$ & ED & $\mathrm{Y}$ & $\mathrm{Br}$ & DMC & $\mathrm{RS}$ \\
\hline 391046.14 & Oval & Cream & Cream & shallow & MY & $\mathrm{R}$ & 19.46 & \\
\hline 392657.8 & Oval & Pink & Cream & shallow & HY & $\mathrm{R}$ & 19.28 & \\
\hline 393077.54 & Globe & White & Cream & medium & MY & $\mathrm{R}$ & 18.49 & 1.8 \\
\hline 395096.2 & Globe & $\begin{array}{l}\text { White, pink } \\
\text { points }\end{array}$ & White & medium & $\mathrm{HY}$ & $\mathrm{R}$ & 20.99 & \\
\hline 395112.32 & Globe & Pink & Cream & shallow & HY & $\mathrm{R}$ & 19.02 & 5.2 \\
\hline NAROPOT 3 & Globe & Red & Cream & medium & MY & MR & 20.57 & 2 \\
\hline nkrk19.17 & $\begin{array}{l}\text { short- } \\
\text { oval }\end{array}$ & Pink & Cream & Deep & MY & $\mathrm{R}$ & 18.04 & 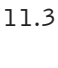 \\
\hline RUTUKU & Oval & Red & Cream & shallow & $\mathrm{HY}$ & $\mathrm{R}$ & 17.72 & 5.8 \\
\hline
\end{tabular}

TS is tuber shape, SC is skin colour, FC is flesh colour, ED is eye depth, $\mathrm{Y}$ is yield, $\mathrm{Br}$ is blight resistance, DMC is dry matter content, RS is reducing sugar, $\mathrm{MY}$ is moderate yield, $\mathrm{HY}$ is high yield, $\mathrm{R}$ is resistant and MR is moderate resistance [21 22]

an open field trial. On $16^{\text {th }}$ August 2018 a field experiment was established towards the start of planting season using a 5 x 6 alpha lattice design with three replications. All the eight parental genotypes and three filler clones were planted as seed potato tubers with nineteen seedling Fl family genotypes. The genotypes were planted in single row plots of ten seedlings. Planting was done by hand and N:P:K, 17:17:17 \% fertilizer was applied at $100 \mathrm{~kg} \mathrm{ha}^{-1}$. Pest and disease control and all agronomic practices were done as recommended.

\section{Data Collection}

Data were collected on yield parameters, dry matter content and reducing sugars. Total tuber yield expressed as tha ${ }^{-1}$ was calculated using number of tubers per plot, total weight of tubers per plot and converted to tons per hectare on an adjusted model of plant population per hectare according to plant spacing used per plot in the experiment. The average weight per tuber was gotten from a function of the number of tubers, and total tuber weight of those numbers of tubers. Dry matter content was quantified by the oven drying method as reported by Esuma et al., [24], were by $200 \mathrm{~g}$ of potato sample of each genotype was weighed, washed under running water and dried with a cloth towel. Then tubers were cut and chopped into smaller pieces and mixed manually to get a homogeneous sample. Approximately $100 \mathrm{~g}$ of each homogenous sample were taken in duplicates for measurement of dry matter content by drying the sample in an oven to constant weight at a temperature of $105^{\circ} \mathrm{c}$. The dried samples were reweighed and the dry matter content was calculated by the formula; (Dry weight of sample/fresh weight of sample) X 100.The average calculation from the duplicate samples was taken as dry matter content per genotype per plot.

Reducing sugars, the 2,4-dinitrophenol solution method as described by Bisognin et al., [25] was used to estimate reducing sugars. Potato tubers per genotype were washed under running water, dried with a cloth towel and the tubers peeled. Then the peeled tubers were chopped into smaller pieces and mixed manually to create a homogenous sample. This chopped sample of each genotype was oven dried at $60^{\circ} \mathrm{c}$ to constant weight. The dried sample was milled into flour. $1 \mathrm{~g}$ of each milled sample per genotype was weighed into a test tube as duplicates, $5 \mathrm{ml}$ 
of distilled water was added. The samples were then vortexed to mix thoroughly and centrifuged at 5000 revolutions per minute. From the supernatant $2 \mathrm{ml}$ was added to $0.5 \mathrm{ml}$ of 2, 4-dinitrophenol solution $(0.038 \mathrm{M})$. The samples were incubated at $70^{\circ} \mathrm{c}$ in a water bath for 6 minutes then cooled off under tap running water. Then reducing sugar absorbencies were read at $600 \mathrm{~nm}$ spectrophotometrically. From these absorbance readings the reducing sugar concentrations present were calculated by tabulation against a standard glucose curve.

\section{Data Analysis}

Data were analyzed using analysis of variance (ANOVA) in GenStat statistical program (18th Edition). Genotypes were considered as fixed effects and where genotype means were significant, means were compared using Fisher's protected least significant difference (LSD) test at $5 \%$ probability level. General combining ability (GCA) and Specific combining ability (SCA) values and the respective variance components were obtained from the ANOVA according to Griffing, [26] model 1 method 2. The variance components were used to determine Baker's ratio in order to estimate the relative importance of additive and non-additive gene effects. The variance components were also used to estimate narrow and broad sense coefficient of genetic determination which are analogous to narrow and broad sense heritability respectively. Heterosis for the progenies was determined through Mid-parent heterosis, This was computed using the following formulas [27].

$$
\text { Mid-Parent Heterosis }(\mathrm{MPH})=(\mathrm{F} 1-\mathrm{mp}) / \mathrm{mp}^{*} 100 \text {; }
$$

T-tests were used to test the significance of heterosis using the following formula

$$
\mathrm{t}_{\mathrm{mp}}=\mathrm{fl}-\mathrm{mp} /\left(\operatorname{sqt}\left(\sigma_{\mathrm{e}}^{2} / 3\right)\right)
$$

In the above formulas; $\mathrm{fl}$ is the mean of progeny; $\mathrm{mp}$ is the mean of two parents in a cross $(\mathrm{P} 1+\mathrm{P} 2) / 2$; sqt is square root; $\sigma_{e}^{2}$ is the error mean square.

Additionally, the average degree of dominance (d/a) was calculated for the Parent $1(\mathrm{Pl}) \times$ Parent $2(\mathrm{P} 2)$ crosses as; $\mathrm{d} / \mathrm{a}=(\mathrm{fl}-\mathrm{mp}) /((\mathrm{Pl}-\mathrm{P} 2) / 2)$, where; $\mathrm{fl}$ is the mean of progeny; $\mathrm{mp}$ is the mean of two parents in a cross, $\mathrm{Pl}$ and $\mathrm{P} 2$ are respectively the parent 1 and parent 2 making up the cross. Interpretation of results was based on the explanations below. $|\mathrm{d} / \mathrm{a}|=1$, if there is complete dominance;

$0<|\mathrm{d} / \mathrm{a}|<1$, if there is partial dominance

$|\mathrm{d} / \mathrm{a}|=0$, if there is no dominance;

$|\mathrm{d} / \mathrm{a}|>1$, if there is over-dominance

\section{RESULTS}

\section{Analysis of Variance}

The analysis of variance revealed significant effects $(\mathrm{P}<0.001)$, for reducing sugars and average weight per tuber while significant $(\mathrm{P}<0.05)$ of the genotypes for dry matter content, total tuber yield of the $\mathrm{Fl}$ progeny and parents (Table 2).

\section{Parental and Family Means}

Parental and family means for dry matter content, total tuber yield, average weight per tuber and reducing sugars are presented in table 3. The mean dry matter content was $18.1 \%$, while reducing sugars was $5.1 \mathrm{mg} / \mathrm{g} / \mathrm{db}$, average weight per tuber was $45.9 \mathrm{~g}$ and total tuber yield was 30.8 tha $^{-1}$. Parent 391046.14 had

Table 2: Means squares for dry matter content, reducing sugars, total tuber yield and average weight per tuber for parents and fl progenies evaluated at Kachwekano from August - December 2018

\begin{tabular}{lccccc}
\hline Source of variation & D.f & DMC $(\%)$ & RS $(\mathrm{mg} / \mathrm{g} / \mathrm{db})$ & TTY $\left(\right.$ tha $\left.^{-1}\right)$ & AWT $(\mathrm{g})$ \\
\hline Replication & 2 & $11.2^{*}$ & 1.9 & $426.3^{*}$ & 127.6 \\
Rep.block & 12 & 2.7 & 1.0 & 119.5 & 299.7 \\
Genotypes & 29 & $5.7^{*}$ & $7.2^{* * *}$ & $265.1^{*}$ & $3695.6^{* * *}$ \\
Residual & 38 & 2.4 & 1.3 & 102.6 & 341.3 \\
L.e.e & 40 & 2.9 & 1.5 & 124.5 & 385.0 \\
\hline
\end{tabular}

$*, * * *$ represent significance level at, $\mathrm{P} \leq 0.05$ and $\mathrm{P} \leq 0.001$ respectively. L.e.e is lattice effective error, D. $f$ is degrees of freedom, DMC is dry matter content, RS is reducing sugars, TTY is total tuber yield and AWT is average weight per tuber

Table 3: Family and parent means for dry matter content, total tuber yield average weight per tuber and reducing sugars

\begin{tabular}{|c|c|c|c|c|}
\hline GENOTYPE & $\begin{array}{c}\text { DMC } \\
(\%)\end{array}$ & $\begin{array}{c}\text { TTY } \\
\left(\text { tha }^{-1}\right)\end{array}$ & $\begin{array}{c}\text { AWT } \\
(g)\end{array}$ & $\begin{array}{c}\mathrm{RS} \\
(\mathrm{mg} / \mathrm{g} / \mathrm{db})\end{array}$ \\
\hline \multicolumn{5}{|l|}{ PROJENIES } \\
\hline $395112.32 \times n k r k 19.17$ & 17.2 & 48.5 & 41.1 & 5.68 \\
\hline $395112.32 \times 395096.2$ & 19.3 & 23.5 & 20.3 & 4.93 \\
\hline $395112.32 \times$ NAROPOT 3 & 17.3 & 35.0 & 26.8 & 6.40 \\
\hline nkrk19.17 x 392657.8 & 17.9 & 23.4 & 25.6 & 4.73 \\
\hline nkrk19.17 x 393077.54 & 18.5 & 25.7 & 21.2 & 5.39 \\
\hline nkrk19.17 x 395096.2 & 16.1 & 29.4 & 19.2 & 4.96 \\
\hline nkrk19.17 x NAROPOT 3 & 18.2 & 27.2 & 29.6 & 6.50 \\
\hline nkrk19.17 x Rutuku & 19.9 & 21.7 & 17.1 & 7.42 \\
\hline $392657.8 \times 391046.14$ & 17.9 & 30.9 & 29.6 & 5.93 \\
\hline $392657.8 \times 393077.54$ & 18.4 & 23.6 & 16.9 & 6.54 \\
\hline $392657.8 \times 395096.2$ & 19.6 & 23.4 & 17.1 & 4.60 \\
\hline $395096.2 \times 391046.14$ & 18.8 & 24.1 & 23.4 & 4.76 \\
\hline NAROPOT $3 \times 391046.14$ & 19.8 & 32.9 & 24.3 & 5.48 \\
\hline NAROPOT $3 \times 393077.54$ & 17.4 & 26.1 & 26.5 & 4.85 \\
\hline NAROPOT $3 \times 395096.2$ & 19.4 & 28.6 & 22.1 & 3.18 \\
\hline NAROPOT $3 \times$ Rutuku & 17.4 & 20.6 & 23.8 & 6.45 \\
\hline Rutuku x 392657.8 & 16.7 & 25.3 & 23.2 & 7.94 \\
\hline Rutuku x 393077.54 & 18.2 & 30.3 & 27.4 & 2.41 \\
\hline Rutuku x 395096.2 & 18.0 & 30.3 & 31.1 & 6.38 \\
\hline \multicolumn{5}{|l|}{ PARENTS } \\
\hline 391046.14 & 20.7 & 17.8 & 28.4 & 5.08 \\
\hline 392657.8 & 18.5 & 32.2 & 81.6 & 3.77 \\
\hline 393077.54 & 17.9 & 41.6 & 125.4 & 4.28 \\
\hline 395096.2 & 18.7 & 27.9 & 69.4 & 4.18 \\
\hline 395112.32 & 15.9 & 34.9 & 130.4 & 6.68 \\
\hline nkrk19.17 & 15.7 & 28.1 & 68.4 & 7.76 \\
\hline NAROPOT 3 & 20.0 & 47.8 & 85.5 & 3.84 \\
\hline RUTUKU & 15.8 & 25.0 & 68.0 & 3.82 \\
\hline MEAN & 18.1 & 30.8 & 45.9 & 5.1 \\
\hline SEM & 0.99 & 11.33 & 6.44 & 0.72 \\
\hline LSD & 2.8 & 18.5 & 32.4 & 2.1 \\
\hline
\end{tabular}
evaluated at Kachwekano from August - December 2018

DMC is dry matter content, TTY is total tuber yield, AWT is average weight per tuber, RS is reducing sugars, SEM is standard error of the mean, and LSD is least significant difference 
the highest dry matter content of $20.7 \%$. Among the progenies, nkrk19.17 x Rutuku (19.9\%) had highest dry matter content. Parent 392657.8 had the lowest reducing sugar of $3.77 \mathrm{mg} / \mathrm{g} / \mathrm{db}$. The lowest cross for reducing sugars was Rutuku x 393077.54 $(2.41 \mathrm{mg} / \mathrm{g} / \mathrm{db})$. Parent 395112.32 had the heaviest tubers at 130.4g. The family cross 395112.32 x nkrk19.17 had the heaviest tubers at $41.1 \mathrm{~g}$.Among the parent genotypes, NAROPOT 3 had the highest yield at 47.8 tha $^{-1}$. The cross 395112.32 x nkrk 19.17 was the highest yielder at 48.5 tha $^{-1}$.

\section{Heterosis Over Mid Parent}

Heterotic effects over mid parent are presented in (Table 4). Dry matter content was both negative and positive mid parent heterosis but only the cross of nkrk19.17 x Rutuku had positive significant mid parent heterosis for dry matter content the rest of the crosses were non-significant for dry matter content. The average degree of dominance (d/a) for dry matter content presented $47.4 \%$ as over dominance and $52.6 \%$ as partial dominance for the crosses in the experiment. Total tuber yield had $395112.32 \times$ nkrk19.17 as positive significant while 392657.8 x 393077.54, NAROPOT 3 x 393077.54, and NAROPOT 3 $\mathrm{x}$ Rutuku were negatively significant. The rest of the crosses had non-significant mid parent heterosis in both positive and negative directions for total tuber yield. The average degree of dominance (d/a) for total tuber yield presented $63.2 \%$ as over dominance and $36.8 \%$ as partial dominance. Average weight per tuber had all the crosses as negative significant. Whereas for the average degree of dominance (d/a) only 392657.8 x 391046.14 , showed partial dominance while the rest of the crosses were over dominant for average weight per tuber. Lastly for reducing sugars Rutuku x 393077.54 and 395112.32 x nkrk19.17 had negative significant mid parent heterosis. The crosses of Rutuku x 392657.8, NAROPOT 3 x Rutuku, 392657.8 x 395096.2 , Rutuku x 395096.2, 392657.8 x 391046.14, and nkrk19.17 x Rutuku had positive significant mid parent heterosis while the rest of the crosses were none-significant mid parent heterosis for reducing sugars.

Table 4: Heterotic effects of dry matter content, total tuber yield average weight per tuber and reducing sugars among the Fl progeny families evaluated at Kachwekano from August - December 2018

\begin{tabular}{|c|c|c|c|c|c|c|c|c|c|c|c|c|c|c|c|c|}
\hline \multirow[b]{2}{*}{ GENOTYPE } & \multicolumn{4}{|c|}{ DMC (\%) } & \multicolumn{4}{|c|}{ TTY (tha-1) } & \multicolumn{4}{|c|}{ AWT (g) } & \multicolumn{4}{|c|}{$\mathrm{RS}(\mathrm{mg} / \mathrm{g} / \mathrm{db})$} \\
\hline & $\mathrm{Fl}$ & MP & $\mathrm{MPH}$ & $\mathrm{d} / \mathrm{a}$ & $\mathrm{Fl}$ & MP & $\mathrm{MPH}$ & $d / a$ & $\mathrm{Fl}$ & MP & $\mathrm{MPH}$ & $d / a$ & $\mathrm{Fl}$ & MP & $\mathrm{MPH}$ & $d / a$ \\
\hline $\begin{array}{l}392657.8 \\
\times 391046.14\end{array}$ & 17.94 & 19.6 & -8.4 & -1.49 & 30.9 & 25.0 & 23.5 & 0.8 & 29.6 & 55.0 & $-46.1^{*}$ & -1.0 & 5.93 & 4.4 & $34.1 *$ & 2.3 \\
\hline $\begin{array}{l}392657.8 \\
\times 393077.54\end{array}$ & 18.43 & 18.2 & 1.3 & 0.84 & 23.6 & 36.9 & $-36.0 *$ & -2.8 & 16.9 & 103.5 & $-83.6 * * *$ & -4.0 & 6.54 & 4.0 & $62.5 * * *$ & 9.9 \\
\hline $\begin{array}{l}392657.8 \\
\times 395096.2\end{array}$ & 19.57 & 18.6 & 5.2 & 7.31 & 23.4 & 30.0 & -22.0 & -3.1 & 17.1 & 75.5 & $-77.4 * * *$ & -9.6 & 4.60 & 4.0 & 15.8 & 3.1 \\
\hline $\begin{array}{l}395096.2 \\
\times 391046.14\end{array}$ & 18.84 & 19.7 & -4.4 & -0.89 & 24.1 & 22.8 & 5.6 & 0.3 & 23.4 & 48.9 & $-52.1 *$ & -1.2 & 4.76 & 4.6 & 2.7 & 0.3 \\
\hline $\begin{array}{r}395112.32 \\
\times 395096.2\end{array}$ & 19.29 & 17.3 & 11.3 & 1.40 & 23.5 & 31.4 & -25.2 & -2.2 & 20.3 & 99.9 & $-79.6 * * *$ & -2.6 & 4.93 & 5.4 & -9.2 & -0.4 \\
\hline $\begin{array}{l}395112.32 \\
\text { xNAROPOT } 3\end{array}$ & 17.30 & 18.0 & -3.8 & -0.33 & 35.0 & 41.4 & -15.3 & -1.0 & 26.8 & 107.9 & $-75.1 * * *$ & -3.6 & 6.40 & 5.3 & 21.6 & 0.8 \\
\hline $\begin{array}{l}395112.32 \\
\text { xnkrk19.17 }\end{array}$ & 17.17 & 15.8 & 8.7 & 9.74 & 48.5 & 31.5 & $53.7 * *$ & 5.0 & 41.1 & 99.4 & $-58.7 * * *$ & -1.9 & 5.68 & 7.2 & $-21.3 *$ & -2.9 \\
\hline $\begin{array}{l}\text { NAROPOT } 3 \\
\times 391046.14\end{array}$ & 19.76 & 20.4 & -2.9 & -1.78 & 32.9 & 32.8 & 0.4 & 0.0 & 24.3 & 56.9 & $-57.3 * *$ & -1.1 & 5.48 & 4.5 & 22.9 & 1.7 \\
\hline $\begin{array}{l}\text { NAROPOT } 3 \\
\times 393077.54\end{array}$ & 17.39 & 19.0 & -8.4 & -1.51 & 26.1 & 44.7 & $-41.6 * *$ & -6.0 & 26.5 & 105.4 & $-74.8 * * *$ & -4.0 & 4.85 & 4.1 & 19.5 & 3.6 \\
\hline $\begin{array}{l}\text { NAROPOT } 3 \\
\times 395096.2\end{array}$ & 19.36 & 19.4 & -0.1 & -0.02 & 28.6 & 37.8 & -24.3 & -0.9 & 22.1 & 77.4 & $-71.4 * * *$ & -6.9 & 3.18 & 4.0 & -20.8 & -4.9 \\
\hline $\begin{array}{l}\text { NAROPOT } 3 \\
\text { xRutuku }\end{array}$ & 17.42 & 17.9 & -2.7 & -0.23 & 20.6 & 36.4 & $-43.4^{*}$ & -1.4 & 23.8 & 76.7 & $-69.0 * * *$ & -6.1 & 6.45 & 3.8 & $68.4 * * *$ & 193.0 \\
\hline $\begin{array}{l}\text { nkrk19.17 x } \\
392657.8\end{array}$ & 17.90 & 17.1 & 4.9 & 0.59 & 23.4 & 30.2 & -22.6 & -3.4 & 25.6 & 75.0 & $-65.9 * * *$ & -7.5 & 4.73 & 5.8 & -17.9 & -0.5 \\
\hline $\begin{array}{l}\text { nkrk19.17 } \\
\text { x393077.54 }\end{array}$ & 18.45 & 16.8 & 9.9 & 1.47 & 25.7 & 34.9 & -26.3 & -1.4 & 21.2 & 96.9 & $-78.1 * * *$ & -2.7 & 5.39 & 6.0 & -10.5 & -0.4 \\
\hline $\begin{array}{l}\text { nkrk19.17 } \\
\times 395096.2\end{array}$ & 16.13 & 17.2 & -6.2 & -0.70 & 29.4 & 28.0 & 4.9 & 9.3 & 19.2 & 68.9 & $-72.1 * * *$ & -102.2 & 4.96 & 6.0 & -16.9 & -0.6 \\
\hline $\begin{array}{l}\text { nkrk19.17 } \\
\text { xNAROPOT } 3\end{array}$ & 18.16 & 17.8 & 1.8 & 0.15 & 27.2 & 38.0 & -28.3 & -1.1 & 29.6 & 76.9 & $-61.5 * * *$ & -5.6 & 6.50 & 5.8 & 11.9 & 0.4 \\
\hline $\begin{array}{l}\text { nkrk19.17 x } \\
\text { Rutuku }\end{array}$ & 19.88 & 15.7 & $26.5 * * *$ & 63.84 & 21.7 & 26.6 & -18.4 & -3.1 & 17.1 & 68.2 & $-74.9 * * *$ & -238.6 & 7.42 & 5.8 & $28.2^{*}$ & 0.8 \\
\hline $\begin{array}{l}\text { Rutuku x } \\
392657.8\end{array}$ & 16.69 & 17.1 & -2.6 & -0.33 & 25.3 & 28.6 & -11.4 & -0.9 & 23.2 & 74.8 & $-69.0 * * *$ & -7.6 & 7.94 & 3.8 & $109.4 * * *$ & 173.3 \\
\hline $\begin{array}{l}\text { Rutuku x } \\
393077.54\end{array}$ & 18.18 & 16.9 & 7.8 & 1.24 & 30.3 & 33.3 & -8.9 & -0.4 & 27.4 & 96.7 & $-71.7 * * *$ & -2.4 & 2.41 & 4.0 & $-40.3 *$ & -7.1 \\
\hline $\begin{array}{l}\text { Rutuku x } \\
395096.2\end{array}$ & 17.95 & 17.3 & 4.0 & 0.47 & 30.3 & 26.4 & 14.8 & 2.7 & 31.1 & 68.7 & $-54.8 * *$ & -53.7 & 6.38 & 4.0 & $59.6 * *$ & 13.1 \\
\hline
\end{tabular}

$*, * *, * * *$ is significance at $(p>0.05),(p>0.001),(p>0.001)$ respectively, MP is mid parent, MPH is mid parent heterosis, $d / a$ is ratio of dominance over additive, DMC is dry matter content, TTY is total tuber yield, AWT is average weight per tuber, and RS is reducing sugars 
Estimates of the Combining Abilities, Variance Components, Baker's Ratio, Narrow and Broad Sense Coefficient of Genetic Determination

Analysis of variance showed highly significant effects $(\mathrm{P}<0.01)$ for GCA and non significant effects for SCA for dry matter content (Table 5). The GCA and SCA effects were not significant for total tuber yield (Table 5). Reducing sugars and average weight of tubers had highly significant GCA and SCA effects at $(\mathrm{P}<0.001)$. Baker's ratio as presented in table 5 was estimated from variance components and 0.58 for dry matter content, 0.44 for total tuber yield, 0.17 for average weight per tuber and 0.28 for reducing sugars. The narrow sense coefficient of genetic determination (NCGD) which is similar to narrow sense heritability and broad sense coefficient of genetic determination (BCGD) analogous to broad sense heritability were estimated from variance components were $29.4 \%$ and $50.6 \%$ respectively for dry matter content, $13.1 \%$ and $29.5 \%$ respectively for total tuber yield, $15.8 \%$ and $90.3 \%$ respectively for average weight per tuber, $21.5 \%$ and $77.8 \%$ respectively for reducing sugars(Table 5 ).

\section{Estimates of General Combining Ability Effects for Parents}

Parents 391046.14 (0.9\%), NAROPOT 3 (0.5\%), 395096.2 $(0.4 \%)$ had highly significant positive GCA effects $(\mathrm{p}<0.001)$ for dry matter content while negative significance GCA effects $(\mathrm{p}<0.001)$ were observed for parents $395112.32(-0.8 \%)$, RUTUKU (-0.6\%) and nkrk19.17 (-0.6\%). The remaining two parents had non-significant GCA effects for dry matter content. Parents $393077.54\left(1.9\right.$ tha $\left.^{-1}\right), 395112.32\left(4.3\right.$ tha $\left.^{-1}\right)$ and NAROPOT 3 (3.6 tha ${ }^{-1}$ ) had a highly significant GCA effects $(\mathrm{p}<0.001)$ for total tuber yield but nkrk19.17 $\left(-0.5\right.$ tha $\left.^{-1}\right)$ was non-significant while all the other parents being negatively significant for total tuber yield. For average weight per tuber parents $393077.54(13.2 \mathrm{~g}), 395112.32(22.2 \mathrm{~g})$ had a highly significant GCA effects $(\mathrm{p}<0.001)$, but 392657.8 $(-0.4 \mathrm{~g})$ was non-significant while all the other parents being negatively significant for average weight per tuber. Parents NAROPOT $3(-0.24 \mathrm{mg} / \mathrm{g} / \mathrm{db}), 395096.2(-0.69 \mathrm{mg} / \mathrm{g} / \mathrm{db})$, $393077.54(-0.63 \mathrm{mg} / \mathrm{g} / \mathrm{db})$, had highly significant negative GCA effects $(\mathrm{p}<0.001)$ for reducing sugars while positive significance GCA effects $(\mathrm{p}<0.001)$ were observed for parents $395112.32(0.55 \mathrm{mg} / \mathrm{d} / \mathrm{db})$, RUTUKU $(0.18 \mathrm{mg} / \mathrm{g} / \mathrm{db}), 392657.8$ $(0.02 \mathrm{mg} / \mathrm{g} / \mathrm{db}) \mathrm{nkrk19.17}(0.87 \mathrm{mg} / \mathrm{g} / \mathrm{db})$, and lastly 391046.14 at $0.08 \mathrm{mg} / \mathrm{g} / \mathrm{db}$ was positively significant at $\mathrm{p}<0.05$ (Table 6).

\section{Estimate of Specific Combining Ability Effects of F1 Progeny Families}

The cross between nkrk19.17 x Rutuku had the highest positive significant SCA effect $(\mathrm{p}<0.01)$ with $2.94 \%$ for dry matter content, while the cross of nkrk19.17 x 395096.2 had the lowest SCA effect for dry matter content at $-1.85 \%$ and was negatively significant at $(\mathrm{p}<0.05)$. The other cross combinations had none significant SCA values for dry matter content. The SCA values for total tuber yield only had the cross between $395112.32 \times$ nkrk19.17 as positively significant $(\mathrm{p}<0.01)$ and
Table 5: Means squares, variance components for dry matter content, total tuber yield, average weight per tuber and reducing sugars for general and specific combining abilities for parents and $\mathrm{Fl}$ progenies respectively evaluated at Kachwekano from August - December2018

\begin{tabular}{lccccc}
\hline Source of variation & DF & DMC (\%) & TTY $\left(\right.$ tha $\left.^{-1}\right)$ & AWT $(g)$ & RS $(\mathrm{mg} / \mathrm{g} / \mathrm{db})$ \\
\hline Crosses & 26 & $1.82 *$ & 55.6 & $1036 * * *$ & $1.9 * * *$ \\
GCA & 7 & $2.96 * *$ & 67.6 & $834 * * *$ & $2.2 * * *$ \\
SCA & 19 & 1.4 & 51.2 & $1110 * * *$ & $1.8 * * *$ \\
Error & 34 & 0.98 & 41.5 & 128.3 & 0.5 \\
VC(GCA) & & 0.29 & 3.9 & 104.0 & 0.2 \\
VC(SCA) & & 0.42 & 9.7 & 981.7 & 1.3 \\
NSCGD (\%) & & 29.4 & 13.1 & 15.8 & 21.5 \\
BSCGD (\%) & & 50.6 & 29.5 & 90.3 & 77.8 \\
BR & & 0.58 & 0.44 & 0.17 & 0.28 \\
\hline
\end{tabular}

$*, * *, * * *$ represent significance level at, $\mathrm{P} \leq 0.05, \mathrm{P} \leq 0.01$ and $\mathrm{P} \leq 0.001$ respectively. DF is degrees of freedom, GCA is general combining ability, SCA is specific combining ability, VC is variance component, NSCGD is narrow sense coefficient of genetic determination, BSCGD is broad sense coefficient of genetic determination, BR is baker's ratio, DMC is dry matter content, TTY is total tuber yield, AWT is average weight per tuber and $\mathrm{RS}$ is reducing sugars

Table 6: General Combining Ability (GCA) values of parents in dry matter content, total tuber yield average weight per tuber and reducing sugars of the $\mathrm{Fl}$ progenies evaluated at Kachwekano from August to December, 2018

\begin{tabular}{lcccc}
\hline PARENT & DMC (\%) & TTY $\left(\right.$ tha $\left.^{-1}\right)$ & AWT $(\mathrm{g})$ & RS $(\mathrm{mg} / \mathrm{g} / \mathrm{db})$ \\
\hline 391046.14 & $0.9 * * *$ & $-3.3 * * *$ & $-9.4 * * *$ & $0.08^{*}$ \\
NAR0P0T 3 & $0.5 * * *$ & $3.6 * * *$ & $-1.9 * * *$ & $-0.24 * * *$ \\
395096.2 & $0.4 * * *$ & $-1.8 * * *$ & $-6.1 * * *$ & $-0.69 * * *$ \\
392657.8 & 0.1 & $-0.7 *$ & -0.4 & $0.02 * * *$ \\
393077.54 & 0.03 & $1.9 * * *$ & $13.2 * * *$ & $-0.63 * * *$ \\
395112.32 & $-0.8 * * *$ & $4.3 * * *$ & $22.2 * * *$ & $0.55 * * *$ \\
RUTUKU & $-0.6 * * *$ & $-3.1 * * *$ & $-3.4 * * *$ & $0.18 * * *$ \\
nkrk19.17 & $-0.6 * * *$ & -0.5 & $-6.6 * * *$ & $0.84 * * *$ \\
SE & 0.23 & 1.51 & 2.65 & 0.2 \\
\hline
\end{tabular}

$*, * * *$ represent significance level at, $\mathrm{P} \leq 0.05$ and $\mathrm{P} \leq 0.001$ respectively. SE is standard error, DMC is dry matter content, TTY is total tuber yield, AWT is average weight per tuber, and RS is reducing sugars

the highest SCA effect value of $15.56\left(\right.$ tha $\left.^{-1}\right)$, however all the other cross combinations had non-significant SCA effects for total tuber yield in both positive and negative directions. For average weight per tuber the cross combinations of 392657.8 x 393077.54, 395112.32 x 395096.2, 395112.32 x NAROPOT 3, NAROPOT 3 × 393077.54, nkrk19.17 x 393077.54 , Rutuku x 393077.54 had negative significant SCA effects, while the rest of the cross combinations had non-significant negative SCA effects. As for reducing sugars, Rutuku x 393077.54 and nkrk19.17 x 392657.8 had negative significant SCA effects at $(\mathrm{p}<0.001)$ and $(\mathrm{p}<0.05)$ respectively. Furthermore the crosses of Rutuku x 392657.8, 392657.8 x 393077.54, Rutuku x 395096.2 were positively significant while the rest of the crosses were nonsignificant SCA values for reducing sugars (Table 7).

\section{DISCUSSION}

The significant GCA mean square for dry matter content shows that additive gene action was involved in the expression of the 
Table 7: Specific Combining Ability (SCA) values of Fl progenies for dry matter content, total tuber yield and average weight per tuber evaluated at Kachwekano from August - December 2018

\begin{tabular}{|c|c|c|c|c|}
\hline GENOTYPE & $\begin{array}{c}\text { DMC } \\
(\%)\end{array}$ & $\begin{array}{c}\text { TTY } \\
\left(\text { tha }^{-1}\right)\end{array}$ & AWT (g) & $\begin{array}{c}\mathrm{RS} \\
(\mathrm{mg} / \mathrm{g} / \mathrm{db})\end{array}$ \\
\hline $392657.8 \times 391046.14$ & -1.14 & 5.7 & -2.2 & 0.50 \\
\hline $392657.8 \times 393077.54$ & 0.23 & -6.7 & $-37.5 * * *$ & $1.82 * *$ \\
\hline $392657.8 \times 395096.2$ & 0.98 & -3.2 & -18.0 & -0.06 \\
\hline $395096.2 \times 391046.14$ & -0.60 & 0.1 & -2.7 & 0.03 \\
\hline $395112.32 \times 395096.2$ & 1.52 & -8.1 & $-37.3 * * *$ & -0.25 \\
\hline $395112.32 \times$ NAROPOT 3 & -0.57 & -1.9 & $-35.1 * * *$ & 0.77 \\
\hline $395112.32 \times$ nkrk19.17 & 0.37 & $15.6 * *$ & -16.2 & -1.03 \\
\hline NAROPOT $3 \times 391046.14$ & 0.23 & 3.5 & -6.1 & 0.31 \\
\hline NAROPOT $3 \times 393077.54$ & -1.26 & -8.5 & $-26.4 * *$ & 0.39 \\
\hline NAROPOT $3 \times 395096.2$ & 0.32 & -2.3 & -11.5 & -1.22 \\
\hline NAROPOT $3 \times$ Rutuku & -0.59 & -9.0 & -12.5 & 1.18 \\
\hline nkrk19.17 x 392657.8 & 0.28 & -4.6 & -9.1 & $-1.46^{*}$ \\
\hline nkrk19.17 × 393077.54 & 0.87 & -4.8 & $-27.0 * *$ & -0.15 \\
\hline$n k r k 19.17 \times 395096.2$ & $-1.85^{*}$ & 2.6 & -9.7 & -0.52 \\
\hline nkrk19.17 x NAROPOT 3 & 0.09 & -5.0 & -3.5 & 0.57 \\
\hline nkrk19.17 x Rutuku & $2.94 * *$ & -3.8 & -14.5 & 1.07 \\
\hline Rutuku x 392657.8 & -0.86 & 0.0 & -14.6 & $2.41 * * *$ \\
\hline Rutuku x 393077.54 & 0.65 & 2.5 & $-24.0 *$ & $-2.47 * * *$ \\
\hline Rutuku x 395096.2 & 0.04 & 6.1 & -1.0 & $1.56^{*}$ \\
\hline S.E & 0.90 & 5.84 & 10.27 & 0.65 \\
\hline
\end{tabular}

trait. In addition the baker's ratio for dry matter content was 0.58 , signifying the predominance of additive genetic effects in controlling dry matter content. The predominance of additive gene action for dry matter content has also been reported by other studies $[18,28]$. These studies reported GCA effects being greater than SCA effects for dry matter content. In contrast the study by Manivel et al., [29], reported non additive gene action for dry matter content in the seedling generation. As for reducing sugars in this study, both additive and none additive gene action were important as both GCA and SCA mean squares were highly significant. These findings are in unison with a study by Jakuczun and Zimnoch-guzowska, [30], who reported both significance of GCA and SCA mean squares on their work with glucose in diploid potato. However in this study the none-additive gene action was more predominant than the additive gene action because of the high broad sense coefficient of genetic determination of $77.8 \%$ and low bakers ratio of 0.28 . These results conform with the study by Parmar et al., [31], who also reported none additive gene action for reducing sugars among the genotypes in that study. Both additive and none additive gene action was involved in the expression of average weight per tuber as both GCA and SCA mean squares were highly significant. These results conform with the study by Galarreta et al., [32], however there other studies that have reported additive gene action to be predominant for average weight per tuber $[33,34,35]$. Additionally in this study the none-additive gene action was more predominant than the additive gene action because of the high broad sense coefficient of genetic determination of $90.3 \%$ and low bakers ratio of 0.17 . The study by Galarreta et al., [32] did also report SCA being more predominant for average weight per tuber than GCA.
None significant GCA and SCA mean squares for total tuber yield shows that there was little genetic diversity among the parents as far as total tuber yield was concerned [35]. But with a baker's ratio of 0.44 it was indicative of a predominance of none additive genetic effects controlling total tuber yield. This is in accordance with other studies that reported SCA effects as greater than GCA effects for yield $[32,33,36]$. However some other authors have observed additive genetic effects being more predominant for total tuber yield $[34,35]$. None the less there still some authors who have reported both additive and non additive genetic gene action to be important for yield $[32,37]$.

These variations in the significance of GCA and SCA effects for traits of this study as compared to other studies could be due to the differences in genetic material used. Additionally the tetrasomic inheritance nature of the potato makes combining ability effects specific to a particular set of genotypes that are used as parent to make a progeny population $[20,35,36,38]$.

A parent to be qualified as good, in that it can pass on a desirable trait is described as that parent which has significant GCA effects in the desirable direction for that trait of interest [39]. The desirable direction for dry matter content and yield components is positive gene action while reducing sugars is negative gene action $[19,35,37,40]$. Both desirable and un-desirable GCA effects were passed on to the respective progenies in this study; parents 391046.14 (0.9), NAROPOT 3 (0.5) and 395096.2 (0.4) (Table 6), had desirable GCA effects for dry matter content while parent 395112.32 (4.3), 393077.4 (1.9) and NAROPOT 3 (3.6) had desirable GCA effects for yield. Parent 395112.32 (22.2) and 393077.4 (13.2) were desirable for average weight per tuber. For reducing sugars parents NAROPOT $3(-0.24)$, 395096.2 (-0.69), and 393077.54 (-0.64), had desirable GCA effects. In this study the highest dry matter content for a cross was a mean of $19.9 \%$ from nkrk19.17 x Rutuku of which both parents had undesirable GCA effects, but it had a significant SCA effect indicating a deviation in performance that was predicted on the basis of GCA of the parents. As explained by Caixeta Franco et al., [41] that high SCA effects manifested by low $\times$ low crosses may be due to dominance $\times$ dominance type of non-allelic gene interaction producing over dominance.

Thirteen of the crosses had negative heterosis for total tuber yield whilst all crosses had negative heterosis for average weight per tuber, this would indicate that parents chosen in the study had narrow genetic base for yield as the parents were chosen as moderate to high yielding (Table 1). The yield classification is according to Namugga et al., [21,22]. They were chosen on dry matter content and the ability to make several successful mating crosses in a half diallel mating design. Similar results of major negative heterosis for yield were reported in a study by Manivel et al., [40]. In a study by Luthra et al., [42] it was reported that the positive significant heterosis for yield was from crosses that were genetically diverse due to the high level of heterozygozity and this finding is in unison with work by Biswas et al., [27]. Furthermore Biswas et al., [27] reported low heterosis of the hybrids from closely related parents. Mendoza et al., [43], justified that in some situations due to close parent relationships we could get hybrids with low heterozygozity, thus leading to the low heterosis 
for that trait. The low heterosis for yield as observed in this study can be explained as due to closely related parents in terms of yield that led to low heterozygozity. Dry matter content in the study had heterosis range of -8.4 to $26.5 \%$ with an average of $2.2 \%$. One cross as positive significant with nine other crosses with positive heterosis. Manivel et al., [40] reported a heterosis range of -12.84 to $9.64 \%$ and a mean of $0.57 \%$ over two clonal generations. The higher mean for this study could be due to the already genetically diverse parents for dry matter content that had a range of 17.72 to $20.99 \%$ (Table 1). The cross of nkrk19.17 $\mathrm{x}$ Rutuku had significant heterosis at mid parent but also at better parent heterosis for dry matter content but negative nonsignificant for yield, indicating that this cross could give clones with high dry matter content but low yield. Similarly still the best heterotic cross even over better parent for yield involved parent nkrk19.17 with the cross of $395112.32 \times$ nkrk19.17 but it was still positive non-significant for dry matter content. These results show a possibility of clone selection with higher yield and low dry matter content but an approach to developing processing varieties should aim at $\geq 20 \%$ dry matter content and moderate yield. The two mentioned crosses did show over dominance for both dry matter content and yield and since both of these crosses showed positive significant heterosis over there better parent the breeder has a choice to select a genotype with optimum dry matter content and or yield. But in this study, selection would have to be on an individual character basis as selection for one character may not necessarily improve the other character.

\section{CONCLUSION}

Results revealed that additive gene effects were involved in expression of dry matter content, both GCA and SCA effects were important for reducing sugars and average weight per tuber but the none additive gene effects were more predominant in the expression of the traits. None additive gene effects were predominant for total tuber yield. In this situation the nature of additive gene action for dry matter content did show that if a breeder gets the parents with good positive GCA effects, improvement of the trait could be achieved through selection of the progenies as the trait can be transferred on to progenies. But for traits where SCA and non-additive genetic action is predominant, further genetic gains can be achieved through hybridization of the desirable parents. In a breeding program the identification of crosses or parents that can be used to get better processing varieties with optimum yield would be a great desire.

In this present study parents NAROPOT 3 and 395096.2 had desirable significant GCA effects in the desirable direction for dry matter content and reducing sugars and are recommended as parents for a hybridization program aimed at improving dry matter content and reducing sugars. Also progeny families of NAROPOT 3 x 391046.14 and NAROPOT 3 x 395096.2 will be subjected to further clonal evaluation.

\section{ACKNOWLEDGEMENTS}

The Makerere University Regional Center for Crop Improvement (MaRCCI) is sincerely thanked for funding this study. Due thanks to the Kachwekano Zonal Agricultural Research and Development Institute (KAZARDI) and the Nutrition and Bioanalytical Laboratory, National Crops Resources Research Institute, for all the support rendered to the corresponding author.

\section{REFERENCES}

1. CIP, . (Centro Internacional de la Papa), 2018. Potato facts and figures WWW Document. URL http://cipotato.org/potato/facts/ (accessed 9.9.18)

2. Scott, G.J., Labarta, R., Suarez, V., 2013. Booms, Busts, and Emerging Markets for Potatoes in East and Central Africa 1961-2010. Potato Research. 56, 205-236. doi:10.1007/s11540-013-9240-2

3. UBOS, 2018. Statistical abstract. Uganda bureau of statistics, 2018.

4. Namugga, P., Melis, R., Sibiya, J., Barekye, A., 2017a. Participatory assessment of potato farming systems, production constraints and cultivar preferences in Uganda. Australian Journal of Crop Science. 11, 932-940. doi:10.21475/ajcs.17.11.08.pne339

5. Tesfaye, A., Lemaga, B., Mwakasendo, J. a, Nzohabonayoz, Z., Mutware, J., Wanda, K.Y., Kinyae, P.M., Ortiz, O., Crissman, C., 2010. Markets for fresh and frozen potato chips in the ASARECA region and the potential for regional trade: Ethiopia, Tanzania, Rwanda, Kenya, Burundi and Uganda. International Potato Center (CIP) No. 2010-1.

6. Kaguongo, W., Gildemacher, P., Demo, P., Wagoire, W., Kinyae, P., Andrade, J., Forbes, G., Fuglie, K., 2008. Farmer practices and adoption of improved potato varieties in kenya and uganda, International Potato Center (CIP). No. 2008-5.

7. Gildemacher, P.R., Kaguongo, W., Ortiz, O., Tesfaye, A., 2009 Improving Potato Production in Kenya, Uganda and Ethiopia: A System Diagnosis. Potato Research. 52, 173=205. doi:10.1007/ s11540-009-9127-4

8. Dick, V., Bradshaw, J., Christiane, G., Francine, G., Donald, K.., Mackenron, Taylor, M.A., Ross, H.A., 2007. Potato Biology and Biotechnology, advances and perspectives. 91-112.

9. Abong, G.O., Okoth, M.W., Karuri, E.G., Kabira, J.N., Mathooko, F.M., 2009a. Evaluation of selected Kenyan potato cultivars for processing into French fries. Journal of Animal and Plant Science. 2, 141-147.

10. Asmamaw, Y., Tekalign, T., 2010. Specific Gravity, Dry Matter Concentration, pH , and Crisp-making Potential of Ethiopian Potato ( Solanum tuberosum L . ) Cultivars as Influenced by Growing Environment and Length of Storage Under Ambient Conditions. Potato Research. 53, 95-109. doi:10.1007/s11540-010-9154-1

11. Ashiv., M., Chraya, P., Singh., B., 2011. French fry quality of potato varieties: effect of tuber maturity and skin curing. Potato Journal. 38 , 130-136

12. Pedreschi, F., 2012. Frying of Potatoes: Physical, Chemical, and Microstructural Changes. Drying Technology. 30, 707-725. doi:10.1 080/07373937.2012.663845

13. Mehta, A., Ezekiel, B.S.R., 2014. Processing quality comparisons in potatoes stored under refrigerated and non-refrigerated conditions. Indian Journal of Plant Physiology. 19, 149-155. doi:10.1007/s40502014-0089-4

14. Abong, G.O., Okoth, M.W., Karuri, E.G., Kabira, J.N., Mathooko, F.M. 2009b. Levels of reducing sugars in eight Kenyan potato cultivars as influenced by stage of maturity and storage conditions. Journal of Animal and Plant Science. 2, 76-84.

15. De Wilde, T., De Meulenaer, B., Mestdagh, F., Govaert, Y., Ooghe, W., Fraselle, S., Demeulemeester, K., Van Peteghem, C., Calus, A., Degroodt, J.M., Verhé, R., 2006. Selection criteria for potato tubers to minimize acrylamide formation during frying. Journal of Agricultural and Food Chemistry. 54, 2199-2205. doi:10.1021/jf0525030

16. Kaur, S., Aggarwal, P., 2014. Studies on Indian Potato Genotypes for their Processing and Nutritional Quality Attributes. International Journal of Current Microbiology and Applied Science. 3, 172-177.

17. Singh, B.P., Kumar, P., 2004. An overview of the factors affecting sugar content of potatoes. Annals of Applied Biology. 145, 247-256.

18. Kesiime, V.E., 2014. Inheritance of Tolerance to Drought from Selected Potato (Solanum tuberosum) Cultivars in Uganda. Msc. Thesis. Makerere University.

19. Bradshaw, J.E., Todd, D., N, R.W., 2000. Use of tuber progeny tests for genetical studies as part of a potato ( Solanum tuberosum subsp 
tuberosum ) breeding programme. Theoretical and Applied Genetics. 100, 772-781.

20. Muthoni, J., Kabira, J., Shimelis, H., Melis, R., 2015a. Tetrasomic inheritance in cultivated potato and implications in conventional breeding. Australian Journal of Crop Science. 9, 185-190.

21. Namugga, P., Sibiya, J., Melis, R., Barekye, A., Namugga, P., Sibiya, J., Melis, R., Phenotypic, A.B., 2017b. Phenotypic characterisation of potato ( Solanum tuberosum ) genotypes in Uganda. South African Journal of Plant and Soil. 1862, 1-8. doi:10.1080/02571862.2017.13 70561

22. Namugga, P., Sibiya, J., Melis, R., Barekye, A., 2018a. Yield Response of Potato ( Solanum tuberosum L.) Genotypes to Late Blight Caused by Phytophthora infestans in Uganda. American Journal of Potato Research. doi:10.1007/s12230-018-9642-4

23. Kakuhenzire, R., Lemaga, B., Kashaija, I., Ortiz, O., Mateeka, B., 2013. Effect of crotalaria falcata in crop rotation and fallowing on potato bacterial wilt incidence, disease severity and latent infection in tubers and field soil. Biopesticides International. 9, 182-194.

24. Esuma, W., Kawuki, R.S., Herselman, L., Labuschagne, M.T., 2016. Diallel analysis of provitamin A carotenoid and dry matter content in cassava (\&lt;i\&gt; Manihot esculenta\&lt;/i\&gt; Crantz). Breeding Science. 66, 627-635. doi:10.1270/jsbbs.15159

25. Bisognin, D.A., Sergio, T. de F., Pereira, E.I.P., Gomez, A.C.S., Brackmann, A., Nicoloso, F., 2012. Processing quality of potato tubers produced during autumn and spring and stored at different temperatures. Horticultura Brasileira. 30, 91-98.

26. Griffing, B., 1956. Concept of general and specific combining ability in relation to diallel crossing systems. Australian Journal of Biological Science. 9, 463-493.

27. Biswas, M.K., Hossain, M., Islam, R., 2008. Utilization of Genetic Diversity and its Association with Heterosis for Progeny Selection in Potato Breeding Programs National Key Laboratory of Crop Genetic Improvement. American-Eurasian Journal of Agricultural and Environmental Sciences. 3, 882-887.

28. Guedes, M.L., Pinto, C.A.B.P., Ribeiro, G.H.M.R., Lyra, D.H., Carneiro, O.L.G., 2016. Combining abilities for agronomic traits and marker-assisted selection for potato virus $X$ and potato virus $Y$ resistance. Genetics and Molecular Research. 15. doi:10.4238/ gmr.15038685

29. Manivel, P., Pandey, S.K., Singh, S. V, 2009. Repeatabilty of general and specific combining ability effects of seedling and clonal generations in potato. Electronic Journal of Plant Breeding. 43-46.

30. Jakuczun, H., Zimnoch-guzowska, E., 2004. Inheritance of Glucose Content in Tubers of Diploid Potato Families. American Journal of Potato Research. 81, 359-370.
31. Parmar, S.K., Rathod, A.H., Khule, A.A., Kanbi, V.H., Patel, C.R. Potato, M., 2015. Assessment of combining ability analysis for developing new genotypes for high tuber yield of potato. The Bioscan. an Internatiional Quarterly Journal of Life Sciences. 10, 2011-2017.

32. Galarreta, J.I.R. de, Ezpeleta, B., Pascualena, J., Ritter, E., 2006 Combining ability and correlations for yield components in early generations of potato breeding. Plant Breeding. 125, 183-186.

33. Gopal, J., 1998. General combining ability and its repeatability in early generations of potato breeding programmes. Potato Research. 41, 21-28. doi:10.1007/BF02360258

34. Muhinyuza, J.B., Shimelis, H., Melis, R., Sibiya, J., Ndambe, M., 2016 Combining ability analysis of yield and late blight Phytophthora infestans ( Mont .) de Bary resistance of potato germplasm in Rwanda. Australian Journal of Biological Science. 799-807. doi:10.21475/ajcs.2016.10.06.p7303

35. Namugga, P., Sibiya, J., Melis, R., Barekye, A., 2018b. Combining ability analysis of earliness and yield of potato (Solanum tuberosum L.) genotypes in Uganda. Euphytica 214. doi:10.1007/s10681-018-2201-8

36. Muthoni, J., Shimelis, H., Melis, R., 2015b. Combining ability analysis of tuber yield and related traits and bacterial wilt ( Ralstonia solanacearum ) resistance in potato. Australian Journal of Crop Science. 9, 401-412.

37. Haydar, a, Alam, M.K., Khokan, E.H., Ara, T., Khalequzzaman, K.M., Agricultural, R., 2009. Combining ability and genetic variability studies in potato. Journal of soil Nature. 3, 1-3.

38. Bradshaw, J.E., Stewart, H.E., Wastie, R.L., Dale, M.F.B., Phillips, M.S. 1995. Use of Seedling Progeny Tests for Genetic-Studies as Part of a Potato (Solanum-Tuberosum Subsp Tuberosum) Breeding Program. Theoretical and Applied Genetics. 90, 899-905.

39. Singh, R. k., Chaudhary, B.D., 2007. Biometrical methods in quantitative genetic analysis. Kalyani, New Delhi, India.

40. Manivel, P., Singh, S.K.P.S. V, Kumar, D., 2010. Heterosis and combining ability for tuber dry matter and yield in potato ( Solanum tuberosum L .) over two clonal generations under short-day subtropic conditions. Electronic Journal of Plant Breeding. 1, 287-296.

41. Caixeta Franco, M., Tulio Cassini, S., Rodrigues Oliveira, V., Vieira, C., Mui Tsai, S., Damiao Cruz, C., 2001. Combining ability for nodulation in common bean (Phaseolus vulgaris L.) genotypes from Andean and Middle American gene pools. Euphytica 118, 265-270. doi:10.1023/A:1017560118666

42. Luthra, S.K., Gopal, J., Sharma, P.C., 2005. Genetic Divergence and it's Relationship with Heterosis in Potato. Potato Journal. 32, 37-42.

43. Mendoza, H.A., Haynes, F.L., Science, H., 1974. Genetic Basis of Heterosis for Yield in the Autotetraploid Potato. Theoretical and Applied Genetics. 45, 21-25. 